\title{
Effects of the Electrical Stimulation of the Mammary Nerve on Oxytocin and Luteinizing Hormone Secretion in Anesthetized Rats
}

\author{
Kei-ichiro Maeda, Naganari Ohkura, Emi Uchida, \\ Hiroko Tsukamura and Akira Yokoyama \\ Laboratory of Reproductive Physiology, School of Agriculture, \\ Nagoya University, Nagoya 464-01
}

(Accepted for publication April 1, 1988)

\begin{abstract}
Summary. Effects of the electrical stimulation of the mammary nerve on oxytocin (OT) and luteinizing hormone (LH) secretion in anesthetized lactating rats were examined. The electrical stimulation of the mammary nerve as well as the saphenous and the median nerve increased the plasma OT concentration in both lactating and cycling rats under urethane anesthesia. All groups of rats stimulated with these nerves showed a very similar pattern of OT release which was different from those observed in lactating rats suckled by pups. The electrical stimulation of the mammary nerve decreased the plasma LH concentration in ovariectomized lactating rats that had been deprived of their pups for $24 \mathrm{hr}$ compared with the concentration obtained after the stimulation of the saphenous nerve. The possibility still remains that the electrical stimulation of the mammary nerve could be used as a substitute for the suckling stimulus. KEY WORDS; LACTATION, RAT, LH, OXYTOCIN, MAMMARY NERVE.
\end{abstract}

Jpn J Anim Reprod 34, 153-158, 1988

\section{Introduction}

Suppression of luteinizing hormone (LH) secretion during lactation which causes the blockade of ovulation has been reported in many mammalian species (Howie and McNeilly, 1982; Edwards and Foxcroft, 1983; Walters et al., 1982; Fox and Smith, 1984). The intimate relationship between mothers and their litter, especially suckling of teats by pups might be the most significant factor involved in the suppression of LH release, because abeyance of suckling by removing pups induces an increase in LH secretion and recurrence of ovulation in rats (Taya and Sasamoto, 1980), and frequency of the breast feeding in women (Howie and McNeilly, 1982) or milking in cows (Peters et al., 1981) affects length of the postpartum anovulatory period.

The intensity and frequency of the suckling stimulus might be important factors in regulating the pituitary hormone secretion. They could be changing with the advance of lactation or physiological condition of mothers: e.g. the number of pups (Fox and Smith, 1984) and the degree of pups development (Jakubowski \& Terkel, 1986). Mena et al. $(1978 ; 1980)$ reported the rise in intramammary pressure and the plasma prolactin concentration after the electrical stimulation of the mammary nerve. This suggests the possibility that the electrical stimulation of the mammary nerve could be a substitute for the suckling stimulus by pups. However, little work has been conducted on the usefulness of the electrical stimulation of the mammary nerve in studying the hormonal changes induced by the suckling stimulus.

To determine whether or not the electrical stimulation of the mammary nerve could be used 
as a substitute for the suckling stimulus in lactating rats, following 2 experiments were performed. First, we examined the effect of the electrical stimulation of the mammary nerve on the OT secretion which shows a sharp response to the suckling by pups (Higuchi et al., 1986). Second, the effectiveness of the electrical stimulation of the mammary nerve in suppressing the pulsatile LH secretion in lactating rats which had been deprived of their pups for several hours were examined.

\section{Materials and Methods}

\section{Animals and treatments}

Female Wistar-Imamichi strain rats weighing $250-300 \mathrm{~g}$ were maintained in a light- (14L: 10D, lights-on $0500 \mathrm{~h})$ and temperature- $\left(24 \pm 2^{\circ} \mathrm{C}\right)$ controlled room with free access to food and water. Pregnant females were placed into individual maternity cages immediately after mating. The day of parturition was designated day 0 of lactation. The size of litters was adjusted to 8 on day 1 of lactation. Ovaries were removed under ether anesthesia on day 2 of lactation in animals used in Experiment 2.

Experiment 1: The mammary nerve of lactating rats which had been deprived of their pups for $17-18 \mathrm{hr}$ on day 8-10 of lactation and cycling rats which had shown at least 2 consecutive regular estrous cycle was electrically stimulated, and the change of plasma OT levels was examined. Lactating and cycling rats were anesthetized with urethane $(130 \mathrm{mg} / \mathrm{kg} \mathrm{BW})$. Their mammary nerves, without cutting, were exposed carefully by the slightly modified method of Mena et al. (1978), and covered with the skin for $1 \mathrm{hr}$. One hour after the exposure, the nerve was placed upon a bipolar stainless steel electrode $(0.8 \mathrm{~mm}, 3 \mathrm{~mm}$ distance $)$ and $10 \mathrm{sec}$ stimulation was repeated 3 times at $5 \mathrm{~min}$ interval with the following parameters that had been reported to be most effective in increasing the intramammary pressure (Mena et al., 1978): $3 \mathrm{msec}$ pulses $(50 / \mathrm{sec})$ at $10 \mathrm{~V}$. These square wave pulses were generated by an electric stimulater (DPS-151, Dia Medical System, Tokyo, Japan) connected an isolation unit (DPS-122). The saphenous and median nerves were exposed and electrically stimulated as controls with the same procedures used for the mammary nerve. Blood samples
$(100 \mu \mathrm{l})$ were taken at $15-60 \mathrm{sec}$ interval through the indwelling atrial cannula fixed the day before sampling. Plasma was separated by immediate centrifugation at $4{ }^{\circ} \mathrm{C}$ and stored at $-20^{\circ} \mathrm{C}$ until assayed for OT.

Experiment 2: The effect of the electrical stimulation of the mammary nerve on the pulsatile LH secretion in ovariectomized lactating rats on day 8 of lactation that had been deprived of their pups for $24 \mathrm{hr}$ was examined. Lactating rats were anesthetized with thiopental (Ravonal, Tanabe, Osaka, Japan) infusion (10-15 mg/hr) which had been reported to have little effects on pulsatile LH secretion (Kawakami et al., 1982). The mammary nerve was exposed as mentioned above. One hour after the exposure, the batches of the electrical stimulation of the mammary nerve $(3$ times $10 \mathrm{sec}$ of stimulation at $5 \mathrm{sec}$ interval) were applied repeatedly every $5 \mathrm{~min}$ for either 1 or $2 \mathrm{hr}$. The parameter of the stimulation was the same as that used in Experiment 1. Blood samples $(100 \mu \mathrm{l})$ were collected at $6 \mathrm{~min}$ intervals for $3 \mathrm{hr}$ from the termination of the stimulation. Conscious lactating rats with or without 1-hr resuckling after 24-hr separation of pups were also bled at $6 \mathrm{~min}$ intervals for $3 \mathrm{hr}$.

Sham-stimulated rats received the same treatment as the mammary nerve-stimulated rats without the stimulation in both experiments served as control.

\section{Hormone assays}

Plasma OT concentrations were determined by a specific double-antibody radioimmunoassay described previously (Higuchi et al., 1986). The antiserum against OT was supplied by Dr. Higuchi of Fukui Medical School, Japan. [125I]OT and synthesized OT were purchased from Amersham Japan, Inc., Tokyo, Japan and Peptide Laboratories Inc., Osaka, Japan, respectively. Fifty $\mu$ l of plasma was assayed without any extraction procedures. The intra- and inter-assay coefficients of variation were $7.5 \%$ at the level of $11.5 \mathrm{pg} /$ tube and $16.5 \%$ at the level of 12.6 $\mathrm{pg} /$ tube, respectively.

Plasma LH concentrations were determined by a sensitive heterologous double-antibody radioimmunoassay (Fox and Smith, 1984). The antiserum against ovine LH was supplied by Dr. Niswender of Colorado University, Fort Collins, USA. Values are expressed in terms of the NIADD 


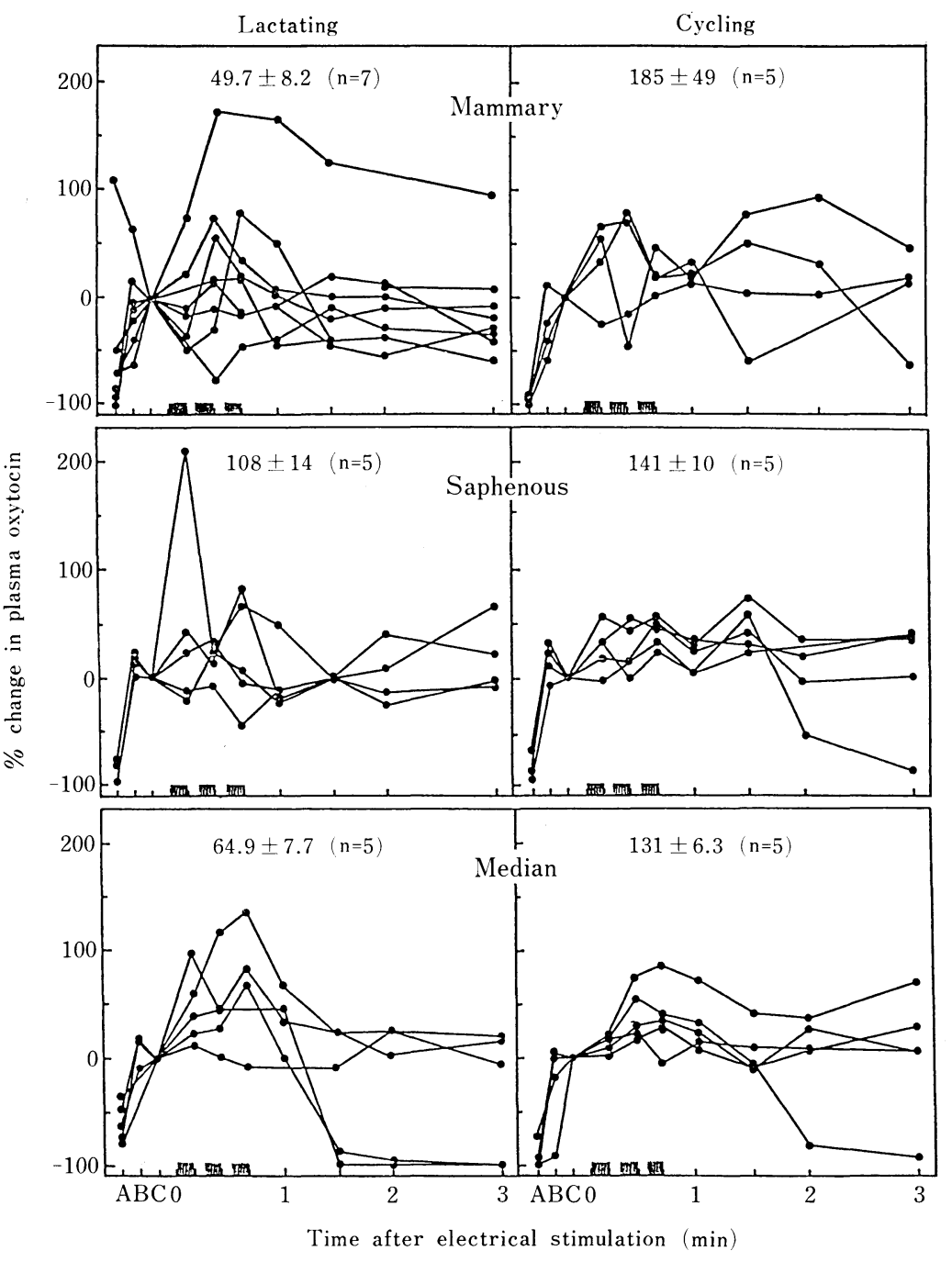

Fig. 1. Percent changes in plasma oxytocin concentrations in lactating (left panels) and cycling (right panels) rats stimulated with the mammary (upper panels), saphenous (middle panels) and median (lower panels) nerves under anesthesia. All lactating rats had been deprived of their pups for preceding $24 \mathrm{hr}$. The onset of stimulation is designated time 0 . Shaded areas and values in each panel indicate the duration of the electrical stimulation and plasma OT concentrations at time 0 . A: before anesthesia, B: after anesthesia and exposure of the nerve, $\mathrm{C}$ : just before the onset of stimulation.

reference standard RP-2. The intra- and interassay coefficients of variation were $14.4 \%$ at the level of $30.9 \mathrm{pg} /$ tube and $9.2 \%$ at the level of 29.0 $\mathrm{pg} /$ tube, respectively.

LH pulse analysis

Pulses in a series of plasma $\mathrm{LH}$ concentrations in each rat were identified with the PULSAR computer program (Merriam and Wachter, 1982) supplied by Dr. Merriam of NICHHD, Bethesda, USA. The program was slightly modified for the application to the computer system of Nagoya University Computation Center. The criteria in our pulse analysis were previously described (Maeda et al., 1987). The S.D. for each LH level was calculated from the first regression line determined by assaying 10 replicates of 4 plasma 


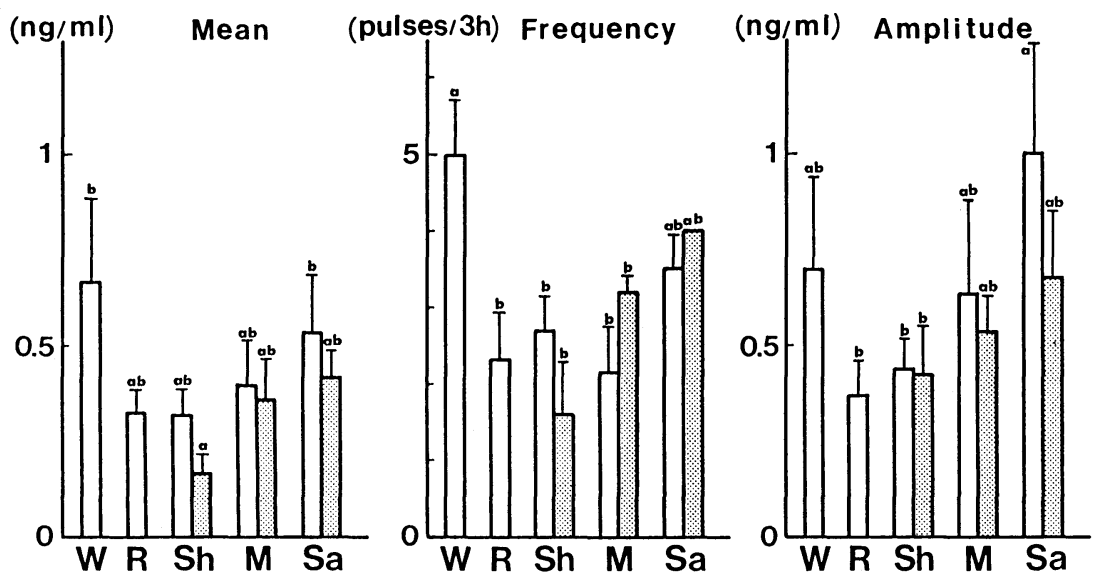

Fig. 2. Changes in mean LH concentration (left panel), LH pulse frequency (middle panel) and LH pulse amplitude (right panel) after the electrical stimulation of the mammary or saphenous nerve for 1 (open column) or 2 (dotted column) hours in anesthetized lactating rats. All rats had been deprived of their pups for preceding $24 \mathrm{hr}$. Vertical bars represent SEM. Different letters on the top of each column mean the significant difference $(\mathbf{P}<0.01$, Duncan's multiple range test). W: conscious rats without stimulation, $\mathbf{R}$ : conscious rats resuckling for $1 \mathrm{hr}$, Sh: sham-stimulated, $\mathbf{M}$ : mammary nerve-stimulated, Sa: saphenous nerve-stimulated.

pools in a single assay (e.g. $\mathrm{Y}=0.153 \mathrm{X}+0.035$ ). Statistical analysis

Statistical differences were determined by MannWhitney $U$ test or one-way ANOVA followed by Duncan's multiple range test.

\section{Results}

Experiment 1: The plasma OT concentration increased immediately after the onset of electrical stimulation of the mammary, saphenous or median nerve in lactating rats as well as cycling rats (Fig. 1). The OT concentration reached a peak during the stimulation and then gradually decreased to the initial level just before the stimulation. The values of plasma OT concentrations just after placing the nerves on the electrode, however, were already higher than that just before placing. The mean of plasma OT concentrations during the 3-min sampling period in cycling rats was higher than that in lactating rats, although there was no significant difference (Mann-Whitney $\mathrm{U}$ test). The pattern of the changes in the concentrations varied from animal to animal. Some animals showed a rapid increase or decrease in plasma OT concentrations associated with the onset or termination of the electrical stimulation, while some animals did not show any change throughout the stimulation.

Experiment 2: The mean LH concentration, and the frequency and the amplitude of $\mathrm{LH}$ pulses during the 3-h sampling period showed a very low level in rats resuckled by their pups for $1 \mathrm{hr}$ after the separation of pups for $24 \mathrm{hr}$ compared to those in rats without resuckling, indicating that the 1-hr resuckling could be enough to suppress the LH secretion (Fig. 2). Sham-stimulated rats showed a similar level in these 3 parameters of pulsatile LH secretion to those of rats resuckled for $1 \mathrm{hr}$. The mean LH concentration and the frequency and amplitude of LH pulses were lower in mammary nervestimulated rats than those in saphenous nervestimulated control rats $(\mathrm{P}<0.01$, Duncan's multiple range test). The electrical stimulation for $2 \mathrm{hr}$ showed almost the same effect on pulsatile $\mathrm{LH}$ secretion as that for $1 \mathrm{hr}$.

\section{Discussion}

The present result demonstrates that the rise in the intramammary pressure after the electrical stimulation of the mammary nerve reported previously (Mena et al., 1978; Maeda unpublished observations) could be due to the increase in the plasma OT concentration. In cycling rats, the 
electrical stimulation of not only the mammary nerve but also other two nerves, saphenous and median nerves, could increase the plasma OT concentration as well as in lactating rats. These results imply that the stimulus inducing OT secretion might be a sensory input from both nipples and other areas where the tactile stimulus from pups could attain; i.e. the electrical stimulation of the saphenous or the median nerve could mimick the pups attachment to the areas innervated by these nerves and release OT. Another possibility that the electrical stimulation of these nerves might act as a kind of stress and increased the plasma OT concentration deserves consideration, since OT release induced by various kinds of stress has been reported (Lang et al., 1983; Carter et al., 1986), and since the median nerve seemed to have little relation to the suckling by pups. Moreover, the patterns of the change in plasma OT concentration after the electrical stimulation of these three nerves were different from those during the suckling by pups (Higuchi et al., 1986). The OT peak during suckling are much sharper than that observed during the electrical stimulation of these nerves in the present study.

The thiopental anesthesia decreased the frequency as well as the amplitude of $\mathrm{LH}$ pulses in sham-stimulated controls contrary to our preliminary results (data not shown) and the previous report (Kawakami et al., 1982) in ovariectomized rats. The anesthesia with thiopental infusion did not affect the LH pulse frequency but slightly decreased the LH pulse amplitude in our preliminary experiment using non-lactating ovariectomized animals. The anesthesia with thiopental infusion seems to be not suitable for the experiment in which the $\mathrm{LH}$ secretion in lactating rats is examined.

The mean plasma LH concentration, and the frequency and the amplitude of $\mathrm{LH}$ pulses in mammary nerve-stimulated rats were kept at the similar level as in rats resuckled for $1 \mathrm{hr}$. The $\mathrm{LH}$ secretion was not so suppressed in the saphenous nerve-stimulated controls as in sham-stimulated rats. They showed a similar pattern of LH secretion to unanesthetized ovariectomized lactating rats deprived of their pups for $24 \mathrm{hr}$. There might be a difference in the effect on $\mathrm{LH}$ secretion between the electrical stimulation of the mammary and the saphenous nerves. It is most likely that the electrical stimulation of the mammary nerve acted like a suckling and a stress and the stimulation of the saphenous nerve did only like a stress. These results do not negate the possibility that the electrical stimulation of the mammary nerve could be used as a substitute for the suckling stimulus by pups in suppressing the LH secretion.

The suckling stimulus might be a specific stimulus which causes the synchronization of the burst of oxytocinergic neurons (Lincoln et al., 1985) and the almost complete inhibition of $\mathrm{LH}$ secretion without any cooperation of sex steroids (Fox and Smith, 1984; Maeda et al., 1987). The stimulus is transmitted only through the spinal cord probably as a sensory input, because dissection of the spinal cord blocks the milk ejection completely (Fukuoka et al., 1984). Therefore, the electrical stimulation with suitable parameters of the nerves which innervate the nipples could induce similar changes in the hormone secretion to those observed in the suckling.

\section{Acknowledgements}

We thank to NIDDK, NHPP and University of Maryland School of Medicine for a gift of $\mathrm{LH}$ assay kits, to Dr. G.D. Niswender for a gift of antiserum to LH, to Dr. T. Higuchi for a gift of antiserum to oxytocin and to Dr. G. Merriam for gifts of PULSAR computer program. The computation was performed at Nagoya University Computation Center. This work was supported in part by Grant-in-Aid (Nos. 62760221 and 61480076) from The Ministry of Education, Science and Culture, Japan.

\section{References}

Carter DA, Williams TDM, Lightman SL (1986) A sex difference in endogenous opioid regulation of the posterior pituitary response to stress in the rat. J Endocr 111: 239-244.

Edwards S, Foxcroft GR (1983) Endocrine changes in sows weaned at two stages of lactation. J Reprod Fert 67: 161-172.

Fox SR, Smith MS (1984) The suppression of pulsatile luteinizing hormone secretion during lactation in the rat. Endocrinology 115: 2045-2051.

Fukuoka T, Negoro H, Honda K, Higuchi T, Nishida E (1984) Spinal pathway of the milk-ejection reflex in the rat. Biol Reprod 30: 74-81.

Higuchi T, Tadokoro Y, Honda K, Negoro H (1986) 
Detailed analysis of blood oxytocin levels during suckling and parturition in the rat. $J$ Endocr 110: 251-256.

Howie PW, McNeilly AS (1982) Effect of breastfeeding patterns on human birth intervals. $J$ Reprod Fert 65: 545-557.

Jakubowski M, Terkel J (1986) Prolactin release and milk ejection in rats suckling underfed pups. Endocrinology 118: 8-13.

Kawakami M, Uemura T, Hayashi R (1982) Electrophysiological correlates of pulsatile gonadotropin release in rats. Neuroendocrinol 35: 63-67.

Lang RE, Heil JWE, Ganten D, Hermann K, Unger $\mathrm{T}$, Rascher W (1983) Oxytocin unlike vasopressin is a stress hormone in the rat. Neuroendocrinol 37: 314-316.

Lincoln DW, Fraser HM, Lincoln GA, Martin GB, McNeilly AS (1985) Hypothalamic pulse generators. Recent Prog Horm Res 41: 369-419.

Maeda K-I, Tsukamura H, Yokoyama A (1987) Suppression of luteinizing hormone secretion is removed at late lactation in ovariectomized lactating rats. Endocrinol Japon 34: 709-716.

Mena F, Pacheco P, Aguayo D, Clapp C, Grosvenor CE
(1978) A rise in intramammary pressure follows electrical stimulation of mammary nerve in anesthetized rats. Endocrinology 103: 1929-1936.

Mena F, Pacheco P, Grosvenor CE (1980) Effect of electrical stimulation of mammary nerve upon pituitary and plasma prolactin concentrations in anesthetized lactating rats. Endocrinology 106: $458-462$.

Merriam GR, Wachter KW (1982) Algorithms for the study of episodic hormone secretion. Am J Physiol 243: E310-E318.

Peters AR, Lamming GE, Fisher MW (1981) A comparison of plasma $\mathrm{LH}$ concentrations in milked and suckling post-partum cows. J Reprod Fert 62: $567-573$.

Taya K, Sasamoto S (1980) Initiation of follicular maturation and ovulation after removal of the litter from the lactating rat. $J$ Endocr 87: 393-400.

Walters DL, Kaltenbach CC, Dunn TG, Short RE (1982) Pituitary and ovarian function in postpartum beef cows. I. Effect of suckling on serum and follicular fluid hormones and follicular gonadotropin receptors. Biol Reprod 26: 640-646.

\title{
乳腺神経の電気刺激が雌ラットのオキシトシン及び 性腺刺激ホルモン分泌に及ぼす効果
}

\author{
前多敬一郎 - 大倉 永也 - 内田 恵美 - 束村 博子 - 横山 昭 \\ 名古屋大学農学部家畜繁殖学教室
}

乳子による吸乳刺激の代用としての乳腺神経の電気刺 激の有用性を検討するため泌乳あるいは発情周期中の雌 ラットの乳腺神経をウレタンあるいはチオペンタール麻 酔下で電気刺激し，それぞれオキシトシン (OT) と黄体 形成ホルモン (LH) の分泌に及ぼす影響を調べた。泌乳 ラットに打ける乳腺神経の電気刺激は OT の分泌を促進 した。しかし，この電気刺激は発情周期中にあるラット においてもその OTの分泌を増加させた。さらに，伏在 ならびに正中神経の電気刺激も泌乳及び正常発情周期中 のラットにおいて血中 OT 濃度を增加させた。これらの 神䋂の電気刺激による血中 OT 濃度の変化はすべて類似
していた。しかし，乳子による吸乳時にみられるような 変化とは異なっていた。泌乳ラットに抢けるチオペンタ 一ル麻酔下における乳腺神経の電気刺激は伏在神経の電 気刺激に比較して平均血中 $\mathrm{LH}$ 濃度および $\mathrm{LH}$ パルス の頻度並びに振幅を抑制した。以上の結果から，乳腺神 経あるいは他の神経の電気刺激が非特異的に働いてオキ シトシン分泌を促進したと考えられる。しかし，LH 分 泌に関しては伏在神経刺激対照群に比較して乳腺神経の 電気刺激により強く抑制されたことから，乳腺神経刺激 が吸乳刺激に変わる刺激として用いられる可能性は残さ れていると考えた。 